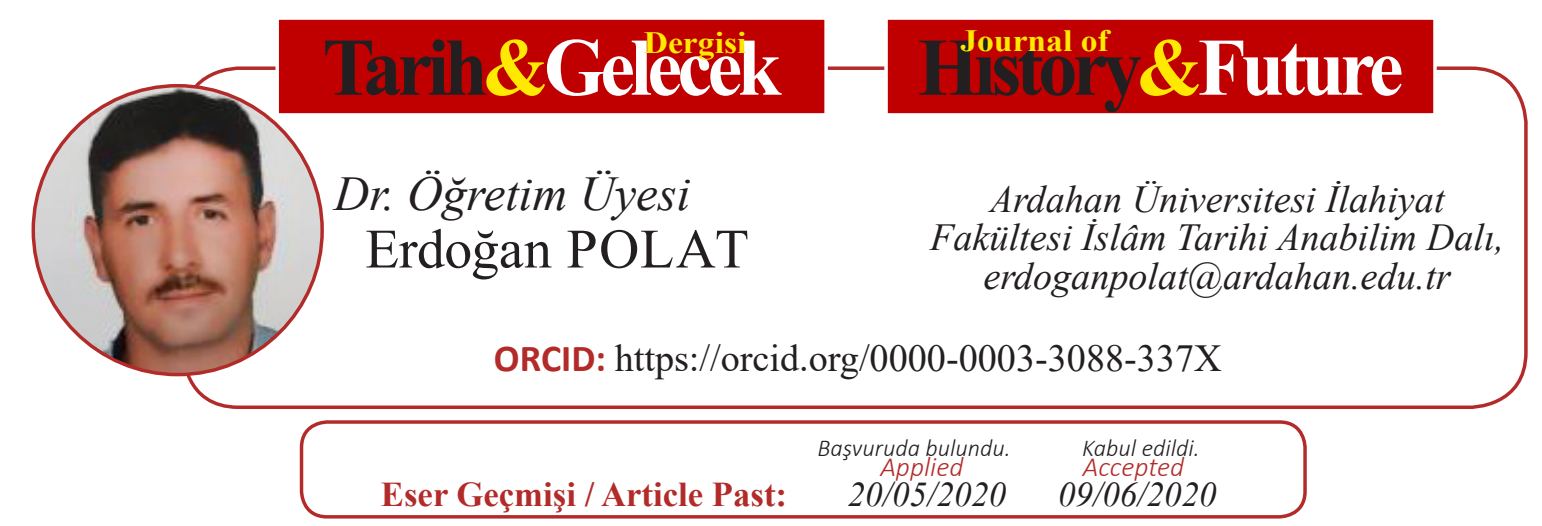

Araștırma Makalesi

DOI: http://dx.doi.org/10.21551/jhf.740278

Research Paper

Orjinal Makale / Orginal Paper

\title{
Osmanlı Devleti'nde Manastırbend Cezasının Tatbikinde Surp Nişan ve Anna Manastırları Örnekleri
}

\author{
Monastic Confinement in the Ottoman Empire with a Focus On the \\ Sourb Nshan and Anna Monasteries
}

$\ddot{O}_{z}$

Osmanlı Devleti'nde Müslüman unsurlarla astrlarca uyumlu bir şekilde yaşayan Hıristiyan reaya, Millet Sistemi denilen ve başında patriklerin bulunduğu bir yapı içerisinde teşkilatlanmışlardı. Osmanlı'da gayrimüslim tebaa evlenme, boşanma, nafaka, velayet, vasiyet, miras, vekâlet, vakıf kurma gibi birçok hukuki konuda kendi milletlerinin kurallarına ve ruhani liderlerine tabi idiler. Ruhban sınıfinın başı olan patriklerin kendi milletinden suç işleyenlere padişahın onayından sonra tatbik ettikleri bazı cezalar söz konusuydu. Sürgünün bir çeşidi olan ve kimi zaman kuleye kapatılmayı da kapsayan manastırbend edilme de bunlardan biriydi. 11. yüzyllda Sivas'ta inşa edilmiş olan Surp Nişan Manastırl, Ermeni patrikliğinin Sivas Başpiskoposluğu'na yüzlerce yıl ev sahipliği yapmış olan önemli bir dini yapıydı. Ermeni patriği bu merkezi yapıyı ruhban sınıfından olan kimi suçluyu manastırbend etmek için kullandı̆̆l gibi bölgedeki Tokat Anna Manastırı 'nı da bu amaçla kullanmıştır. Bu çalışmada, sürgünün dinî bir çeşidi olan manastırbend cezası Osmanlı taşrasında incelenirken ilgili iki manastır merkeze alınmıştır. 19. yüzyılda önemli bir Ermeni nüfusunu barındıran Sivas Eyaleti'ndeki bu dinî ve içtimâ̂ yapıların bu çeşit işlevleri belgeler yardımıyla gösterilmeye çalışılmıştır.

Anahtar Kelimler: Osmanlı Devleti, Gayrimüslimler, Manastırbend, Sivas Surp Nişan Manastırı, Tokat Anna Manastırı.

* Osmanlı Devleti'nde Sürgün Siyasetinin Eyâlet-i Rûm'daki Yansımaları (XIX. Yüzyıl) başlıklı doktora tezinden türetilmiştir.

ATIF: POLAT Erdoğan, “Osmanlı Devleti’nde Manastırbend Cezasının Tatbikinde Surp Nişan ve Anna Manastırları Örnekleri”, Tarih ve Gelecek Dergisi, 6/2 (Haziran 2020), s. (410-422) 


\section{Abstract}

The Christian rayah, who peacefully lived together with Muslim subjects in the Ottoman Empire for centuries, were organized within a structure called the Ottoman Millet (Nation) system managed by the patriarchs. Non-Muslim subjects of the Ottoman Empire had to follow their own spiritual leaders and obey the rules of their own millet in many legal areas including marriage, divorce, alimony, custody, wills, deceased estates, powers of attorney, and the establishment of foundations in non-Muslim subjects in the Ottoman Empire. The patriarchs, the highest ranking religious leaders among the clergy, could punish those from their own millet if they perpetrated a crime, however, the punishment could only be administered after approval by the padishah. Monastic confinement was one mode of punishment. This penalty was a kind of banishment and would sometimes include imprisonment in a tower. Built in Sivas in the 11th Century, the Monastery of Sourb Nshan was an important religious building which played host to the Sivas archbishopric of the Armenian Patriarch for hundreds of years. The Armenian Patriarch used this central building, along with the Anna Monastery of Tokat, for the monastic confinement of offenders from among the clergy. Based on documentary evidence, this study focuses on these two monasteries to shed light on monastic confinement, which was a kind of religious banishment in the Ottoman's outer "taşra" regions, and attempts to explore the religious and social diversity witnessed in the Sivas Eyalet which was home to a significant Armenian population in the 19th Century.

Keywords: Ottoman Empire, Non-Muslims, Monastic Confinement, Sourb Nshan Monastery of Sivas, Anna Monastery of Tokat.

\section{Giriş}

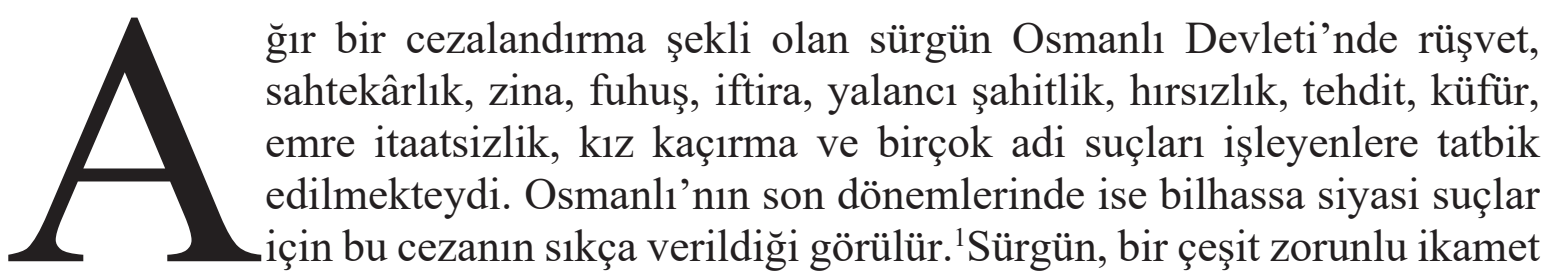
cezasıdır. Sürgün yeri; suçun niteliğine, suçlunun devlet hizmetindeki mevkiine veya statüsüne göre değişebilirdi. Suçluların firarını engellemek ve onları zabt ü rapt altında tutabilmek için sürgün mahalli olarak çoğunlukla adalar veya sahil kaleleri tercih edilmiştir. Bozcaada, Midilli, Sakız, Girit, Rodos ve Kıbrıs gibi Akdeniz adalarının yanında Trabzon, Sinop gibi bazı sahil şehirlerinden de menfa olarak faydalanılmıştır. Ağır suçlular ise merkeze hayli uzak Kuzey Afrika ve Arap coğrafyasının muhtelif yerleşim yerlerine sürgün edilmiştir. Buna mukabil suçu nispeten daha hafif olan sadrazam gibi yöneticiler ile ilmiye sınıfı mensupları Malkara, Dimetoka gibi İstanbul'a civar yerler ile Bursa, İzmir, Kütahya gibi merkeze yakın ve gelişmiş Anadolu şehirlerine nefyedilmişlerdir. Sürgün cezası bazen tek başına, umumiyetle de başka bir cezayla birlikte uygulanmıştır. Cezaya çarptırılan şahıs bir kamu görevlisi ise mutlaka azledilmekte, mansıp ve unvanları geri alınmakta, suçun

1 Kemal Daşcıŏlu, Osmanlı Devleti’nin Sürgün Siyaseti (XVIII. Yüzyıl), Süleyman Demirel Üniversitesi Sosyal Bilimler Enstitüsü, Isparta 2004 (Yayımlanmamış Doktora Tezi). s.167-168. 
büyüklüğüne göre malları kısmen veya tamamen müsadere edilmekteydi. ${ }^{2}$

Sürgün genel anlamda ağır bir ceza kabul edilmekle birlikte Osmanlı Devleti'nde uygulanmakta olan idam, kürek ve hapis cezaları ile mukayese edildiğinde daha hafif bir ceza olarak görülmüştür. ${ }^{3}$ Sürgün cezası eski hukuk literatürümüzde "nefy" ya da "nefy ü tăgrîb" gibi kelimelerle ifade edilmiştir. ${ }^{4}$ Osmanlı Devleti'nde sürgün kelimesi yerine kalebend, ikamete memur-ikamete mecbur, nefy, inhâ, iclâ, teb 'id, mütebâidin, nefy ü irsâl, sarf ü tahvîl, menfî gibi kelimeler de tercih edilmiştir. Sürgün gidilen yerler için ise menfa kelimesi kullanılmıştır. Sürgüne gönderilen kişiye menfi denilirken bu kelimelerin tam tersi af ve salıverilmelerde ise itlak, afv ü itlak, sebil veya ttlâk-1 sebil, sebilîn kelimeleri kullanılmıştır. ${ }^{5}$ Sürgünlerin maaş, mülkiyet vesaire haklarının birbirinden farklı olduğunu savunan M. Çağatay Uluçay'a göre nefy, tağrib, iclâ, ikamete memur gibi sürgünlerin çeşitli dereceleri de vardır. Yazara göre, "kale", kışla, cezire" bendlik gibi cezalarla, sürgün cezası arasında önemli bir farkın olduğu da derhâl göze çarpmaktadır. ${ }^{6}$

Suçluların kale surları içinde ikamete tâbi tutulup hisardan dışarıya çıkmalarına izin verilmemesi şeklinde uygulanan cezayı ifade eden kalebend yanında kapalı mekânlarda tutulan mahkûmlara zindanbend, bir ada üzerinde serbest dolaşmalarına izin verilenlere cezirebend, kaleye göre daha küçük olan askerî amaçlarla yapılmış palankalarda tutulanlara da palankabend denmiştir. Özellikle gayrimüslim tebaadan olan suçlulardan manastırlarda muhafaza edilenlerine manastırbend, kulelerde tutulanlara da kulebend ismi verilmiştir. $^{7}$

\section{Osmanlılarda Tecziye Mekânları Olarak Manastırlar}

Bizanslılar, sınırları içerisindeki farklı kitleleri sürgün ederek bu durumdan askerî, ekonomik ve sosyal birtakım çıkarlar sağlamışlardır. ${ }^{8}$ Doğu Roma İmparatorluğu'nda Hıristiyanlığın kabul edilmemesi bir suç sayılmamakla beraber eski dinlerine bağlı kalanların dinî ayin ve merasim icraları ağır cezalara sebep olurdu. Kendi arazilerinde ayin icrasına müsaade edenlere mallarının müsaderesi, memuriyetten mahrumiyet ve Justinianus (527565) zamanında sürgün cezası reva görülüyordu. Adalar, Prens Adaları, İstanbul Adaları ya da Kızıl Adalar şeklinde isimlendirilen ve Marmara Denizi'nin kuzeydoğu kesiminde yer alan ve kısaca Adalar olarak anılan takımadaları Bizans İmparatorluğu zamanında sürgün yeri olarak kullanılmaktaydı. Adalar'da yer alan manastırlar Bizans İmparatorluğu'nun 10 asrı boyunca her tarikata mensup rahiplerin istifade ettiği önemli bir dinî merkezdi. Çoğunlukla muhtelif imparatorluk sülalelerine mensup prens ve prensesler tarafından tesis edilen bu

2 Osman Köksal, “Osmanlı Hukukunda Bir Ceza Olarak Sürgün ve İki Osmanlı Sultanının Sürgünle İlgili Hatt1-1 Hümayunları", Ankara Üniversitesi Osmanlı Tarihi Araştırma ve Uygulama Merkezi Dergisi, sy.19, (2006) :287-288.

3 Suha Oğuz Baytimur, Osmanlı Devletinde Hapis ve Sürgün Cezaları (1791-1808), (Doktora Tezi, Fırat Üniversitesi, 2011).

4 Ömer Nasuhi Bilmen, Hukukı İslamiyye ve Istılahatı Fıkhiyye Kamusu, (İstanbul, Bilmen Basım ve Yayınevi, 1955),3/306-307.

5 Abdullah Acehan, "Osmanlı Devletinin Sürgün Politikası ve Sürgün Yerleri”, Uluslararası Sosyal Araştırmalar Dergisi, Volume 1/5, (Fall 2008),13.

6 Bu cezalar arasında en önemli farkın mekânın sınırlandırılmasından kaynaklandığı kanaatindeyiz.

7 Ömer İşbilir, “Kalebend”, TDV İslâm Ansiklopedisi., Ek-2, (2016), 5-7.

8 Talip Türcan, "Sürgün”, TDV İslâm Ansiklopedisi, (2010), 38/164. 
manastırlar, Bizans tarihinin en meşhur şahsiyetleri için bir menfa vazifesi görmüştür. Bu manastırlar; tahtından indirilmiş imparatorların, mağlup edilmiş saltanat müddeilerinin, ihanete uğramış nazırların, saray entrikalarına uğrayan prenslerin, rahibeliğe zorlanan imparatoriçelerin, prenseslerin hayal kırıklıklarına ve yok oluşlarına şahitlik etmiştir. ${ }^{9}$

Osmanlı Devleti, İstanbul'un fethi ile birlikte burada yaşayan gayrimüslimlere müntesibi oldukları dinî inançlarını ibraz etme, yaşama, dinlerini kendilerinden sonraki nesillere aktarma, mabetlerini koruma ve tamir ettirme, gerektiğinde yenisini inşa etme ve cemaatin ihtiyaç duyduğu din adamlarını yetiştirme gibi birçok hak tanımıştır. ${ }^{10}$ Osmanlı millet sistemi, tek tek gayrimüslim halkı muhatap almak yerine onların mensup oldukları cemaatin yöneticilerini muhatap kabul etmiştir. Bu çerçevede Yahudileri, Rumları ve Ermenileri müstakil birer millet kabul eden Osmanlı yöneticileri bu bağlamda Rum patriğinin yetkilerini genişleterek o dönemlerde henüz sınırlan içerisinde yer almayan İskenderiye, Kıbrıs ve Kudüs Patrikliği'ni de kendisine bağlamıştır. Yine 1461 yılında Ermeni Patrikliği'nin kurulmasına müsaade ederek yakın dini düşünceye sahip olan Kopt, Habeş ve Süryani Patrikliği'ni de buraya bağlamıştır. Bununla da kalınmamış, Rum ve Ermeni Patrikliği ile ilgili ayrı ayrı nizamnameler düzenlenerek patriklerin yetki ve sorumluluklarını belirlemiştir. Her hükümdar döneminde bu nizamnameler şurut-1 milel-i muhtelife adıyla yenilenmiştir. ${ }^{11}$ Osmanlı'nın asırlar boyunca tatbik ettiği çok milletli düzen diğer imparatorluklara kıyaslandığında son derece insancıldı. Hiçbir gayrimüslim cemaat dilinden, örfünden ve inancından dolayı baskıya ve zulme maruz bırakılmamıştır.

Manastır, belli bir Hıristiyan tarikatına mensup fertlerin çalışma, eğitim ve ibadetlerini tamamen Tanrı'ya has kılmak üzere toplumdan ayrı bir cemaat halinde yaşayabilmelerini temin etmek maksadıyla düzenlenmiş olan yapı ya da yapılar topluluğudur. Hıristiyan manastır hayatının kaynağı Mısır'dır. Bu yaşam tarzı 3. yüzyılın sonlarında insanların, yalnızlık içinde oruç tutmak ve tefekküre dalmak maksadıyla çöllere ve dağlara çekilmeleri şeklinde başlamıştır. ${ }^{12}$ Manastırbend cezası, Osmanlı Hıristiyanlarına patrikleri aracılı̆̆ıyla uygulanan bir sürgün cezasıdır ve kimi zaman kuleye kapatılmayı (kulebend) da kapsar. Manastırbend kayıtlarında patrikler Divan-ı Hümayun'a sundukları arzuhallerinde kimin, nerede, hangi suçları işlediklerini belirttikten sonra failin bulunduğu yerden alınıp sürgün yeri olarak belirli bir manastıra götürülmesini talep eder. $\mathrm{Bu}$ arzuhallerde manastırbend suçunu gerektiren durumlar belirli kalıplarla ifade edilmiştir; "Kendü hâlinde olmamak, ayine mugayir harekâta cesaret etmek, ef' âl-i şent' aya ictisâr etmek, nice harekât-l nâbercâya ictisâr etmek, '1rz ve edebe ve evzâ'-i nâhemvâra ibtidâr eylemek, şekâvet üzere olmak, nâsêzâa hâlât / hilâf-ı rıâ hareket [içinde olmak]”veya bunların birleşimiyle ifade edilen fiillerin ayrıntıları her zaman resmi yazışmalarda belirtilmemiştir. Patriklerin arzuhallerindeki

9 Gustave Schlumberger, İstanbul Adalarl, çev. Naci Yüngül, İstanbul-Eminönü Halkevi Dil, Tarih ve Edebiyat Şubesi Neşriyatı III, (Bürhaneddin Basımevi, İstanbul 1937), 12-13.

10 Mehmet Mahfuz Söylemez, "Kalebend Cezası Bağlamında Osmanlı'da Patrikhanenin Yargılama ve Ceza Ehliyeti Üzerine Bazı Notlar”, Dinsel ve Kültürel Farklılıkların Birarada Yaşaması: İstanbul Tecrübesi (ed. Mehmet Fatih Arslan, Muhammed Veysel Bilici), (İstanbul, Pelikan Basım, 2010) 136-137.

11 Gayrimüslimlerin Bursa'daki durumu hakkında geniş bilgi için bkz. Ali İhsan Karataş, Mahkeme Sicillerine Göre XVIII. Yüzyılda Bursa’da Gayri Müslimler, (Doktora Tezi, Uludağ Üniversitesi, 2005).

12 Karen Kingsley, "Manastır Mimarisi Üzerine”, Uludağ Üniversitesi İlahiyat Fakültesi Dergisi, çev. Salih Çift, c.12, sy.2, (2003): 349-360. 
talepleri Osmanlı idaresi tarafından genellikle kabul edilerek uygulanmıştır. Bunun üzerine suçlu şahıs bulunduğu yerden çoğu zaman yasakç1 ${ }^{13}$ bazen de mütesellim, çavuş veya voyvoda aracığıyla alınıp sürgün yerine götürülürdü. Arzuhaller incelenip gerekli evrak kontrol edildikten sonra hem failin bulunduğu hem de sürgün edileceği yerdeki kadı, naib, bey, dizdar gibi görevlilere gereken fermanlar gönderilirdi. Bu fermanlarda emr-i hümayun olmadıkça suçlunun kesinlikle salıverilmemesi emredilirdi. 18. yüzyılın ikinci yarısından sonra sunulan arzuhallerde sürgün edilmiş kişilerin patrikhaneden gelen mühürlü arzuhal olmadıkça salıverilmemesi uygun bir dille talep edilirdi. ${ }^{14}$

Manastırbend belgelerinde cezanın ne kadar süreceği kesin olarak belirtilmez ve "ıslâh-ı nefs" edinceye kadar kalacakları ifade edilir. Itlak için kimi zaman güvenilir kişilerin kefil olduğu görülmektedir. Bazı durumlarda da af ve salıverilme için bazı şartlar koşulmakta, bunlar yerine getirilmediği takdirde ise daha şiddetli bir şekilde cezalandırılacakları belirtilmektedir. Sürgünden kurtulanlar da bundan sonra "kendi hallerinde olacaklarını" taahhüt etmektedirler. Sürecin uygulanmasına dair belgelerde patriğin otoritesinin kaynağ 1 olarak padişahın verdiği yetkinin yanı sıra Osmanlı Ortodoksları nezdindeki dini otorite de bulunmaktadır. Dini otoritesine dayanarak patriğin de burada ifade ettiği gibi, manastırbend uygulamasında faillerin toplumdan tecrit edilerek vereceği zararı engellemenin yanı sıra suçluların manastırda manevi bir dönüşüm geçirebilecekleri düşüncesi de etkili olmuş görünmektedir. ${ }^{15}$

Osmanlı Devleti zamanında gayrimüslimler ahval-ı şahsiye alanına giren evlenme, boşanma, nafaka, velayet, vasiyet, miras, vekâlet, vakıf kurma gibi birçok konuda kendi milletlerinin kurallarına ve ruhani liderlerine tabi idiler. Bu konular daha çok dinî akitler çerçevesinde değerlendirildikleri için bunları yalnızca kendi din adamlarının yetkisinde icrasına rıza gösterilmekteydi. Bundan dolayı bazı belgelerde patrikliğin evlenme ile boşanma konusunda köy ve mahalle imamlarının gayrimüslimlere ait nikâhları kıymamaları ve ehl-i örfün de bu konuda cebir kullanmamaları yönünde sık sık devlete müracaatlarının olduğu görülmektedir. Ruhani reislerin kendi milletinden suç işleyenlere uyguladıkları bazı cezalar söz konusuydu. Elbette bu cezalar Osmanlı padişahının onayından sonra tatbik edilebiliyordu. Sürgün, kalebend etme, küreğe vurma, falaka-değnek cezaları yanında sadece din adamlarına uyguladıkları kulebend etme ve manastırbend etme bunlardan bazılarıydı. Ayrıca devletin âyinleri üzere te'dip oluna şeklindeki ceza talepleri ise daha çok kilisede

13 Osmanlı Devleti'ne misafir gelen elçi heyetlerinin korunması devletin görevleri arasındaydı. Devlet bunların güvenliğini sağlamak üzere sınırdan girişlerinden çıkışlarına kadar yanlarına yeniçeriler görevlendirirdi. Elçinin korunmasından sorumlu olan bu yeniçerilere yasakçı ismi verilirdi (Ahmed Akgündüz, Osmanlı Kanunnameleri ve Hukukî Tahlilleri,Fey Yayınları, c.4, İstanbul 1992, 141). Bir elçiye dört yeniçeri yasakçısı ve bir çavuş tayin edilirdi. Osmanlı'nın elçi ve maiyetindekiler için endişelenmesinin bir sebebi de kaçırılarak satılmaları tehlikesiydi. 2 Safer 976 (27 Temmuz 1568) tarihli Amasya beyine yazılan iki hükümde İran'dan elçi ile birlikte gelen Ahverdî’nin Merzifon'da mallarını gasp edip dokuz gün hapseden ve kendisini başka bir vilayete satmak isteyen Erzurum kullarından Pîri ve Hızır'ın şayet Amasya'ya gelirlerse takip edilerek yakalanıp hapsedilmeleri, Ahverdi'nin de mallarının iade edilmesini istenmiştir. Bkz. Ömer Düzbakar, "XV-XVIII. Yüzyıllarda Osmanlı Devleti’nde Elçilik Geleneği ve Elçi İaşelerinin Karşılanmasında Bursa’nın Yeri”, Uluslararası Sosyal Araştırmalar Dergisi, c.2, sy.6, (2007) : 190 .

14 Elif Bayraktar Tellan, "Osmanlı Araştırmalarında Yeni Kaynakların Tarihyazılımına Katkıları: Manastırbend Örneği”, Tarihyazımı, 1(2), (Kış 2019): 178-180.

15 Tellan, “Osmanlı Araştırmalarında Yeni Kaynakların Tarihyazılımına Katkıları: Manastırbend Örneği”, 181. 
yemin ettirme, aforoz etme, kiliseye sokmama, ölenlerin cenazelerini kaldırmama şeklinde uygulanan cezaları ifade etmekteydi. Ruhani liderler uygun görülen cezaların infazı için devletten yardim talep edebilmekteydiler. ${ }^{16}$

\section{Sivas Eyaleti'nin Manastırbend Merkezleri}

Hiristiyanlık dünyasında Ermeni Kilisesi Apostolik Ermeni Kilisesi ismi ile de anılan ayrı ve bağımsız bir kilisedir. Ermeni Kilisesi'nin en önemli ruhani merkezi ise Ecmiatzin görülmekteydi. Ecmiatzin, günümüz Ermenistan Cumhuriyeti'nin başkenti Erivan'a 25 km uzaklıkta eski bir yerleşim yeridir. Kat'oğikosluk, Ermeni Kilisesi'nde en yüksek makamdaki ruhani liderlere verilen unvandır. Bu ruhanî liderin makamının bulunduğu yer ise Kat'oğikosluk merkezi kabul edilmekteydi. Dolayısıyla Ecmiatzin, Ermeni Kilisesi'nin ruhanî idarecisinin makamının bulunduğu yerdir. Ermeni Kilisesi tarihinde Ecmiatzin haricinde başka ruhani merkezler de oluşmuştur. Varlığını uzun süre devam ettirenler şunlardır: Kilikya Kat'oğikosluğu, Ahtamar Kat'oğikosluğu, İstanbul ve Kudüs Patriklikleridir. Ahtamar Kat'oğikosluğu ${ }^{17} 19$.yüzyıl başlarında ortadan kalkmıştır. Diğerleri ise hâlen varlığgını sürdürmektedirler. ${ }^{18}$

Sivas’ta bulunan bazı manastırlar gayrimüslim ruhbanların cezalarının infaz edildiği manastırbend merkezlerindendi. Ruhani liderlerin mühürlü arzuhallerle manastırbend edilmelerini teklif ettikleri din adamlarını yine aynı şekilde 1tlaklarını ancak mühürlü arzuhallerle talep ettikleri yerleşmiş bir usuldü. Daha önce Muş Manastırı murahhası olduğu hâlde memuriyeti esnasında işlediği cürümlerden dolayı önce azledilerek İstanbul'a celp edilmiş olan Ermeni Rahip Zaferye sonrasında Sivas eyaletinde bulunan Surp Nişan ${ }^{19}$ manastırına sürgün edilmişti. Ermeni Rahip oradan da firar ederek Harput ve Diyarbekir taraflarına kaçmıştı. Harput valisiyle Diyarbekir kaymakamına yazılarak firarî sürgünün yakalanması istenirken bu konuda ricada bulunan Ermeni patriği ve millet meclisinin de talebi olduğ $\mathrm{u}^{20}$ bilgisi paylaşılmıştır. Sivas valisine de yazılan şukkayla suçlunun yakalanarak

16 Ercan Yavuz, Osmanlı Yönetiminde Gayrimüslimler: Kuruluştan Tanzimat'a Kadar Sosyal, Ekonomik ve Hukukî Durumları, (Turhan Kitabevi, Ankara, 2001) 203-206.

17 “Gevaş İlçesi’nin sınırları dâhilindeki Akdamar Adası’nda yer almaktadır. Adanın güneydoğusuna kurulmuş olan kilise, Kutsal Haç adına Vaspurakan Kralı I. Gagik tarafından 915-921 yılları arasında Keşiş Manuel'e yaptırılmıştır. Kilisenin kuzeydoğusundaki şapel 1296-1336 tarihlerinde; batısındaki Jamaton 1763 tarihinde; güneyindeki çan kulesi 18. yüzyıl sonlarında ilave edilmiştir. Kuzeyindeki şapelin ise, tarihi bilinmemektedir. İlk yapıldığında saray kilisesi olan yapı, sonradan manastır kilisesine dönüştürülmüştür...” Bkz. http://www.vankulturturizm.gov.tr/TR-76403/akdamar-adasi-ve-kilisesi.html.

18 Canan Seyfeli, Ecmiatzin Kat'oğikosluğu’nun Ermeni Kilisesi’ndeki Yeri, (Doktora Tezi, Ankara Üniversitesi, 2007).

19 Şehrin kuzeyinin yarım saat kadar uzağında ve bir ovanın yüksek yerinde duvarlar ile çevrilmiş bir güzel bahçenin içerisinde Surp Nişan ismine bir mükellef Ermeni manastırı ve kırk kadar odasıyla yeterli sayıda mensubu bulunmaktaydı. Manastırın içerisinde üç adet kilise olup Surp Nişan ismine olan dört köşe ve cilalı taşlar ile kemerleri bulunmaktaydı. Yine mükemmel bir kubbesi olduğu için iç duvarlarının yarısına kadar sırlı ve çiçekli çiniler ile kaplı olması yönünden de meşhurdur. Ayrıntılı bilgi için bkz. Felek Mecmuası, Sahibi Ohannes Balıkcıyan, Cancik Aramyan Matbaası, Sivas 1882; Sivas manastırlarının en ünlüsü olan Surp Nışan Manastırı, 11. yüzyılda inşa edilmiş ve Sivas başpiskoposluğuna ev sahipliği yapmıştır. Bugün yıkılmış olan bu manastırın bulunduğu alan Temeltepe platosundaki askerî bölge içindedir. Bkz. Ermeni Kültür Varlıklarıyla Sivas, Yayına hazırlayanlar, Vahakn Keshishian, Koray Löker, Mehmet Polatel, (Mas Matbaacılık, İstanbul 2018)14-24.

Belge için Bkz. BOA, HR_MKT_55_58_03_01 (13 Rebiülahir 1269/24 Ocak 1853). 
tekrar manastıra yerleştirilmesi istenmiştir. ${ }^{21}$

Ermeni karabaşlarından ${ }^{22}$ Rahip İstefan daha önce Cakılı murahhass ${ }^{23}$ iken idaresine kadir olamadığı ve ayinlere aykırı davranarak toplumun dengesini bozacağı endişesini taşıyan manastırdaki ruhban ve civardaki Ermeni taifesi tarafından şikâyet edilmiştir. Rahibin ${ }^{24}$ murahhaslıktan azledilip yerine bir diğerinin naspı, kendisinin de Hasankale manastırında ikamet etmesi kendisine tembih olunmuşsa da bunu dinlememişti. Hatta tam tersine itaatsizlik anlamına gelecek şekilde istediği yerde gezip milleti isyan ettirecek vaazlarına devam etmiştir. İstanbul ve tevabii Ermeni patriği Karabet, İstefan’ın bulunduğu mahalden yasakçı marifetiyle alınarak Sivas manastırına sürgün edilerek manastırbend edilmesini ve itlağının da yine ancak kendisinin mühürlü arzuhâliyle müsaade edilmesi yönünde emr-i şerif yazılmasını padişaha sunduğu arzuhalle istirham etmiştir. Sivas kadısına gönderilen fermanda manastırbend edilmek üzere yasakçı refakatinde gönderilen rahibi Sivas manastırına menfiyyen yerleştirmesi ve fermansız ıtlağından sakınıp başka bir yere gitmesine de müsaade etmemesi 1240 senesi Şevval ayının son günlerinde (16 Haziran 1825) istenir. ${ }^{25}$ Rahip İstefan'ın aldığ 1 cezadan sonra rahat duracağına dair taahhüdü alındığından bahseden İstanbul ve çevresi Ermeni patriği Karabet, onun İstanbul'a gelmemek şartıyla bu defalık affedilmesini padişaha yazdığı arzuhâlinde ister. Yazışmalar sonrasında Sivas naibinden rahibin yukarıdaki şartlar muvacehesinde affedildiği için 1tlağı işinin takipçisi olması 1241 senesi Cemaziyelevvel'inin ilk günlerinde (12 Aralık 1825) yazılan ferman ile istenir. $^{26}$

Trabzon' da Ermeni murahhası olarak görev yapan İstanbullu Rahip Bogos, raiyyete uymayan tavirlarından ve mezhep ayinlerinin icra şekline muhalif davranmasından dolay1 kendisine nasihat edilmiş ise de bundan mütenebbih olmayarak hatasında 1srar etmişti. Bu durumda rahibin bölgede kalması mahzurlu görüldüğ̈ünden 1slâh-1 nefs edinceye kadar Sivas'ta bulunan Ermeni milletine mahsus Surb Nişan manastırına nefy ü iclâ olunması ve ıtlağının da ancak kendileri tarafından mühürlü yazıyla istendiğinde müsaade olunması hususunda emr-i şerif yazılması İstanbul ve tevabii Ermeni patriği Matyos Bogos tarafindan istirham edilir. Rahibin bahsi geçen manastırda manastırbend edilmesi hususunda ferman gecikmez. Trabzon müşiri Vezir Abdullah Paşa'dan rahibi yakalatması ve mübaşir refakatinde manastıra nefy ü irsale gayret etmesi istenir. Sivas naibinden ise şehirlerine vardığında murahhası manastırda menfiyyen ikamet ettirmesi 1260 senesi Zilkade ayının ortalarında (26 Kasım 1844) talep edilmiştir. İstanbullu Rahip Bogos'un Sivas'a vardıktan sonra menfiyyen ikamet ettirildiğini beyan eden ilâm,3 Safer 1261 (11 Şubat 1845) tarihlidir. ${ }^{27}$

21 BOA, HR_MKT_55_58_01_01 (13 Rebiülahir 1269 / 24 Ocak 1853); ayrica bkz. BOA, HR_ MKT_55_58_01_02 (13 Rebiülahir 1269 / 24 Ocak 1853).

22 Rahip anlamına gelmektedir.

23 Ermeni piskoposu anlamına gelmektedir; bkz. Ferit Devellioğlu,“Murahhas”, Osmanlıca-Türkçe Ansiklopedik Lugat, (Aydın Kitabevi Yayınları, Ankara, 2012) 798.

24 Yazılmış, adı geçmiş. Bu kelime hakaret görmesi icap eden aşağılık kimseler, daha çok düşmanlar hakkında kullanılırdı. Bkz. Devellioğlu,"Mesfûr", s.726.

25 BOA, A_DVNSKLB_d_00037_00109. Ayrica bkz. SŞS, 13/119-3.

26 BOA, A_DVNSKLB_d_00037_00133.

27 SŞS, 21/ 96-3. Ayrica bkz. NFY. KSS2., 35/4. 
Patrik, 1slâh-1 nefs ederek tamamen pişman olmuş ve bundan sonra bu tür davranışlarda bulunmayacağını taahhüt etmiş olan rahibin merhameten afv ü ıtlakı hususunda padişahın müsaadesini istirham eder. Rahibin afv ü itlağına dair ferman ise 1261 senesi Rebiülahir' $i$ nin ortalarında (22 Nisan 1845) yazılmıştır. ${ }^{28}$

Sivas'ta bulunan Surb Nişan manastırı sakinlerinden Rahip Davit"hilaf-l rıza harekete ibtidarı" ndan dolayı yazılan emr-i șerif mucibince cezalandırılmak üzere Tokat'a nefy ü iclâ olunur. Rahibin bundan sonra ayinlere aykırı davranmayacağına dair taahhütte bulunmasından sonra sürgünden affedilmesi babında emr-i şerif yazılmasını İstanbul ve tevabii Ermeni Patriği İsteban, bir kıta mühürlü arzuhâl takdim ederek istirham eder. Bunun üzerine rahibin itlağı için gerekli ferman 1249 senesi Rebiülevvel'inin ilk günlerinde (19 Temmuz 1833) yazılmıştır. ${ }^{29}$

Tokat'ta bulunan Anna isimli manastır da suç işleyen ruhbanların ıslahına hizmet etmekteydi. Karahisar-1 Şarkî'de murahhasas olan Ermeni karabaşı Agob, 1rz ve iffeti ile hareket etmeyerek uygunsuz hareketlere tevessül ederek görevinin icap ettiği şart ve nizamlara aykırı davranışlarda bulunduğundan Karahisar-1 Şarkî'de yasakçı marifetiyle yakalanarak cezalandırılmak üzere Tokat'ta bulunan Anna isimli manastıra manastırbend edilmiştir. ${ }^{30}$ İstanbul Ermeni Patriği Bogos, karabaşın 1tlağ 1 gündeme gelirse kendisinin mühürlü arzuhali olmadıkça buna müsaade olunmaması için emr-i şerif yazılmasını padişaha takdim ettiği mühürlü arzuhâlinde dile getirir. İstanbul'da yazılan fermanda Tokat naibinden suçluyu yasakçıdan teslim aldıktan sonra fermansız 1tlağından kaçınması ve başka bir mahalle salıvermemesi 1234 senesi Zilkade ayının son gününde (19 Eylül 1819) istenir. $^{31}$

Osmanlı tebaasından olmayanların da zaman zaman Anadolu topraklarında sürgüne gönderildiklerini görmekteyiz. Özel işleri için Tiflis'ten İstanbul'a doğru yola çıkan Rus tebaasından Ermeni Rahip Artin, İznikmid'den ${ }^{32}$ geçerken tutuklanır. Yapılan bütün girişimlere rağmen Dersaâdet'e gitmesine müsaade edilmeyen Artin hizmetkârlarıyla birlikte Sivas'a sürgün edilir. Ancak sürgün cezasının çekileceği mahallin manastır yerine şehir merkezi olduğu resmi belgelerden anlaşılmaktadır. Dönemin resmî makamlarının yaptırmış olduğu tahkikatlarda Ermeni rahip hakkındaki bu haksız uygulamanın İstanbul Ermeni patriğinin isteği ve etkisiyle yapıldığı ortaya çıkar. Rahibin sürgününün Gürcü semti kumandanı general tarafindan da tavsiye edilmiş olduğu makam-ı riyasette de ifade edilmiştir. Rahibin serbest bırakılarak İstanbul'a gitmesine ruhsat-l seniyye erzan buyrulması İstanbul Rus Maslahatgüzarlığı'ndan 15 Muharrem 1241 (30 Ağustos 1825) tarihinde istenmiştir. Rahibe verilecek pasaport ise Rusya maslahatgüzarına gönderilir. ${ }^{33}$

28 SŞS, 21/ 125-2. Ayrıca bkz. NFY. KSS2., 57/3.

29 BOA, A_DVNSKLB_d_00039_00069.

30 BOA, A_DVNSKLB_d_00035_00100.

31 BOA, A_DVNSKLB_d_00035_00100.

32 İznikmid, İzmit'in Osmanlı dönemindeki adıdır. Bkz. Tahir Sezen,Osmanlı Yer Adları, (Devlet Arşivleri Genel Müdürlüğü, Ankara 2017) 391.

33 BOA, HAT_922_40094_B_01. 
Öte yandan eyalet merkezinde gerçekleşen her ruhban sürgününün manastırlarda icra edilmediğini de görmekteyiz. Buna dair örnekte görüleceği üzere Merzifon kazası Ermeni kocabaşlarından ${ }^{34}$ Vaniloğlu Ovanis ve Anderyasoğlu Abraham, kazanın ihtisap ${ }^{35}$ memuru olan Halil Ağa'nın iftirasından dolayı Sivas'a sürgün edilmişlerdi. İddiaların asılsız ve bunların suçsuz olduğu daha sonra yapılan tahkikat neticesinde ortaya çıktığından gerek Sivas mahallî meclisince yazılan mazbata gerekse Ermeni patrikliği tarafından mahkûmların affedilmesini niyaz eden dilekçe sadaret kethüdasına gönderilmiştir. Kocabaşların affedilerek vilayetlerine gönderilmelerine izin verilmesi hususu son olarak padişaha arz edilmiştir. ${ }^{36}$

\section{Sonuç}

Osmanlı Devleti’nde yaygın bir cezalandırma şekli olan sürgünün birçok çeşidi uygulanmaktaydı. Patrikler, Millet Sistemi dâhilindeki Osmanlı tebaası gayrimüslim halka suç işlemeleri hâlinde ceza teklifinde bulunabiliyordu. Cezanın tatbiki ise ancak padişahın onayından sonra mümkündü. Ruhban sınıfından olanlar ise sivil halktan ayrı olarak Anadolu'nun birçok bölgesindeki manastırlarda manastırbend edilerek tecziye edilmekteydi. Bu bağlamda Ermeni Patrikliğinin önemli piskoposluk merkezlerinden biri kabul edilen Sivas Surp Nişan Manastırı da ibadet ve eğitim merkezi olmanın yanı sıra bir manastırbend merkeziydi. 11. yüzyılda inşa edilen bu dini yapı yanında Sivas eyaletine bağ 1 Tokat'ta inşa edilmiş olan Anna Manastırı da bir manastırbend olarak suçlu ruhbanların sürgün yeri olarak kullanılmaktaydı. Araştırmamızda örnek olarak gösterildiği üzere bölgeye sürgün edilen her Hıristiyan ruhbanın manastırbend edilmediğini görüyoruz. Ruhbanların bir kısmının ise manastırbendliğe göre daha hafif bir ceza olan kulebend ile cezalandırıldıkları çalışmamızda ortaya konmuştur.

34 Osmanlı Devleti döneminde kocabaşı, âyanın eş anlamlısıdır. Kocabaşı Osmanlı Hıristiyanlarının ileri gelenleri anlamındadır. Hıristiyan ileri gelenlerine, Osmanlı ülkesinin değişik yerlerinde kocabaşı, çorbacı ve arhont denilmekteydi. Bunun yanı sıra bir yöredeki Hıristiyan ileri gelenlerine hem kocabaşı hem de çorbacı denildiği de görülmüştür. Bir başka yöredeki mesela Bulgaristan'daki kocabaşı ve çorbacı olan ileri gelen kimseler farklı konumlarda bulunmaktaydılar. Âyanlar ile kocabaşılar arasında birçok benzerlikler vard1. Genel olarak kocabaşılar, âyanlar gibi ırk, mezhep ve meslek bakımından farklı kökenlidirler. Yani Rum, Ermeni, Bulgar, Sırp ırkından ve Ortodoks, Katolik, Protestan ve Gregoryen mezhebine mensup olup semerci, kaptan, papaz, keşiş, çorbacı ve boyacılıktan kocabaş1lığa seçilenler olurdu. Osmanlı belgelerinde kocabaşı deyimi, şimdilik ilk olarak 1691 tarihli bir hükümde görülürken, ilk kocabaşı seçimi ise 1726 tarihli bir belgede rastlanmıştır. Bkz. Özcan Mert, "Tanzimat Döneminde Çeşme Kocabaş1ları (1839-1876)", XIV. Ciepo Sempozyumu, İzmir 2000, 139-140.

35 Osmanlı Devleti’nde önemli işlevi bulunan devlet memurlarından birisi de muhtesiptir. Özellikle Osmanlı şehir hayatında vazgeçilmez bir yeri vardır. Kadının emrinde olan muhtesipler, umumiyetle çarşı ve pazardaki intizamı sağlamak, temel ihtiyaç maddelerinin ucuz ve uygun bir şekilde halkın eline geçmesini sağlamak, iş yeri açma ruhsatı vermek ve vergi toplamak gibi pek çok görevle mükelleftiler. Şehirlerde genel olarak ticarî faaliyetleri denetlemekle görevli muhtesipler, buna karşılık esnaf ve zanaatkârlardan ihtisap vergisi almaktaydılar. Yönetimlerinden şahsen sorumlu oldukları ve tebaanın kendilerine Allah'ın bir emaneti olarak verildiği telakkisi içerisinde olduklarını belirttiğimiz Osmanlı padişahları, halkın refah seviyelerinin yükseltilmesi "terfih-i ahvalleri" ve korunması hususunda çok hassastılar. Bu amaçla üretici ve tüketiciyi korumaya yönelik olarak, muhtelif mekanizmalar işletilmiş, kurum ve kuruluşlar tesis edilmiş ve pek çok tedbir alınmıştır. İște bunlardan birisi olan geleneksel kurumların başında "lhtisab müessesesi"” gelmektedir. Bkz. İbrahim Erdoğdu, "Osmanlı İktisadî Düzeninde İhtisab Müessesesi ve Muhtesiplik Üzerine Bir Deneme”, Ankara Üniversitesi Osmanlı Tarihi Araştırma ve Uygulama Merkezi Dergisi, sy.11, (2000), 139-141. 


\section{Kaynakça}

\section{T. C. Cumhurbaşkanlığı Devlet Arşivleri Başkanlığı Osmanlı Arşivi}

HR_MKT (Hariciye Nezareti Mektubi Kalemi Evrak1) 55_58_03_01; 55_58_01_02; $55 \quad 58 \_0101$.

A_MKT (Sadaret Mektubi Kalemi Evrakı) 34_65.

HAT (Hatt-1 Hümayun) 922_40094_B_01.

A_DVNSKLB_d (Kalebend Defterleri) 00035_00100; 00037_00133; 00037_00109:00039_00069.

SȘS(Sivas Şer'iyye Sicilleri) 13/119-3; 21/ 96-3; 21/ 125-2.

NFY. KSS2 (Nefy ve Kısas Defterleri) 35/4; 57/3.

İnceleme-Araştırma Eserler

Akgündüz,Ahmed, Osmanlı Kanunnâmeleri ve Hukukî Tahlilleri, c.4, Fey Yayınları, İstanbul, 1992.

Baytimur,Suha Oğuz, Osmanlı Devletinde Hapis ve Sürgün Cezalarl (1791-1808), Doktora Tezi, Firat Üniversitesi, 2011.

Bilmen, Ömer Nasuhi, Hukukı Íslamiyye ve Istılahatı Fıkhiyye Kamusu, c.3, Bilmen Basım ve Yayınevi, İstanbul, 1955.

Daşcıŏglu, Kemal, Osmanlı Devleti’nin Sürgün Siyaseti (XVIII. Yüzyıl), Doktora Tezi, Süleyman Demirel Üniversitesi, 2004.

Düzbakar, Ömer, "XV-XVIII. Yüzyıllarda Osmanlı Devleti’nde Elçilik Geleneği ve Elçi İaşelerinin Karşılanmasında Bursa'nın Yeri”, Uluslararası Sosyal Araştırmalar Dergisi, c.2, sy.6, (2007): 190.

Erdoğdu, İbrahim, "Osmanlı İktisadî Düzeninde İhtisab Müessesesi ve Muhtesiblik Üzerine Bir Deneme", Ankara Üniversitesi Osmanlı Tarihi Araştırma ve Uygulama Merkezi Dergisi, sy.11, (2000): 139-141.

İşbilir, Ömer, "Kalebend", TDV İslâm Ansiklopedisi., Ek-2, (2016): 5-7.

Karataş, Ali İhsan, Mahkeme Sicillerine Göre XVIII. Yüzyılda Bursa'da Gayri Müslimler, Doktora Tezi, Uludağ Üniversitesi, 2005.

Keshishian Vahakn, Koray Löker ve Mehmet Polatel, Ermeni Kültür Varlıklarıyla Sivas, Mas Matbaac1lı, İstanbul, 2018.

Kingsley, Karen, "Manastır Mimarisi Üzerine”, Uludağ Üniversitesi Illahiyat Fakültesi Dergisi, çev. Salih Çift, c.12, sy.2, (2003) :349-360.

Köksal, Osman, "Osmanlı Hukukunda Bir Ceza Olarak Sürgün ve İki Osmanlı Sultanının Sürgünle İlgili Hattı-1 Hümayunları”, Ankara Üniversitesi Osmanlı Tarihi Araştırma ve Uygulama Merkezi Dergisi, sy.19, (2006): 287-288. 
Mert, Özcan, "Tanzimat Döneminde Çeşme Kocabaş1ları (1839-1876)", XIV. Ciepo Seтроzуити, İzmir (2000) :139-140.

Schlumberger, Gustave, İstanbul Adalarl, çev. Naci Yüngül, İstanbul-Eminönü Halkevi Dil, Tarih ve Edebiyat Şubesi Neşriyatı III, İstanbul,Burhaneddin Basımevi, 1937.

Seyfeli, Canan, “Ecmiatzin Kat'oğikosluğu'nun Ermeni Kilisesi’ndeki Yeri”, Doktora Tezi, Ankara Üniversitesi, 2007.

Sezen, Tahir, Osmanlı Yer Adları, Devlet Arşivleri Genel Müdürlüğü, Ankara, 2017.

Söylemez, Mehmet Mahfuz, "Kalebend Cezası Bağlamında Osmanlı'da Patrikhanenin Yargılama ve Ceza Ehliyeti Üzerine Bazı Notlar", Dinsel ve Kültürel Farklılıklann Birarada Yaşaması: İstanbul Tecrübesi (ed. Mehmet Fatih Arslan, Muhammed Veysel Bilici), İstanbul, Pelikan Basım, 2010.

Tellan, Elif Bayraktar, "Osmanlı Araştırmalarında Yeni Kaynakların Tarihyazılımına Katkıları: Manastırbend Örneği”, Tarihyazımı, Kış (2019), c. 1(2) :171190.

Türcan, Talip, “Sürgün”, TDV İslâm Ansiklopedisi, c.38, İstanbul (2010): 164.

Yavuz, Ercan, Osmanl Yönetiminde Gayrimüslimler: Kuruluştan Tanzimat'a Kadar Sosyal, Ekonomik ve Hukukî Durumları, Ankara, Turhan Kitabevi, 2001. 


\section{Ek 1.}

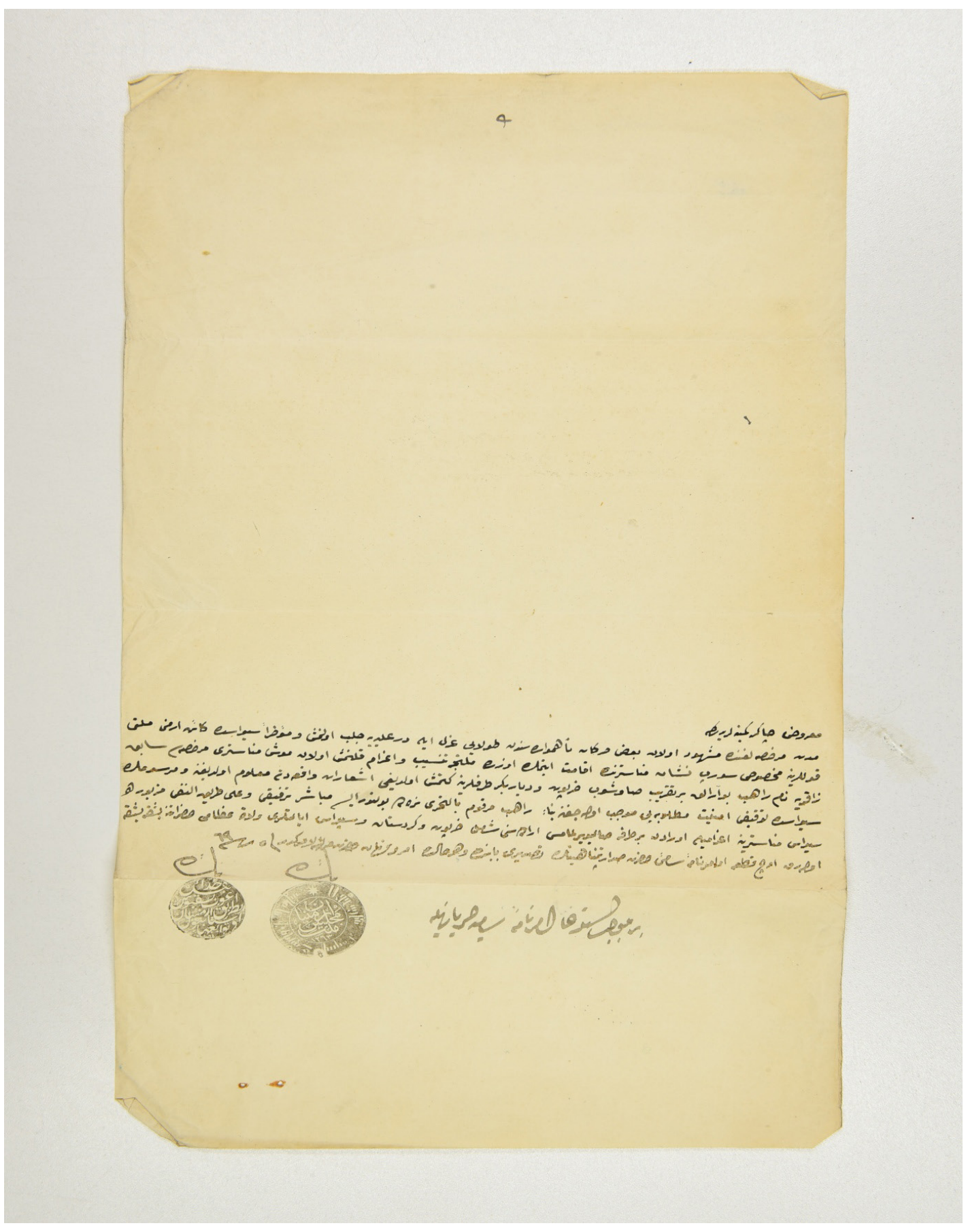

Sivas Surp Nişan Manastırı’na Gönderilen Muş Manastırı Murahhasası Rahip Zaferye Hakkındaki Belge, BOA, HR_MKT_55_58_03_01(13 Rebiülahir 1269) . 
Ek 2.

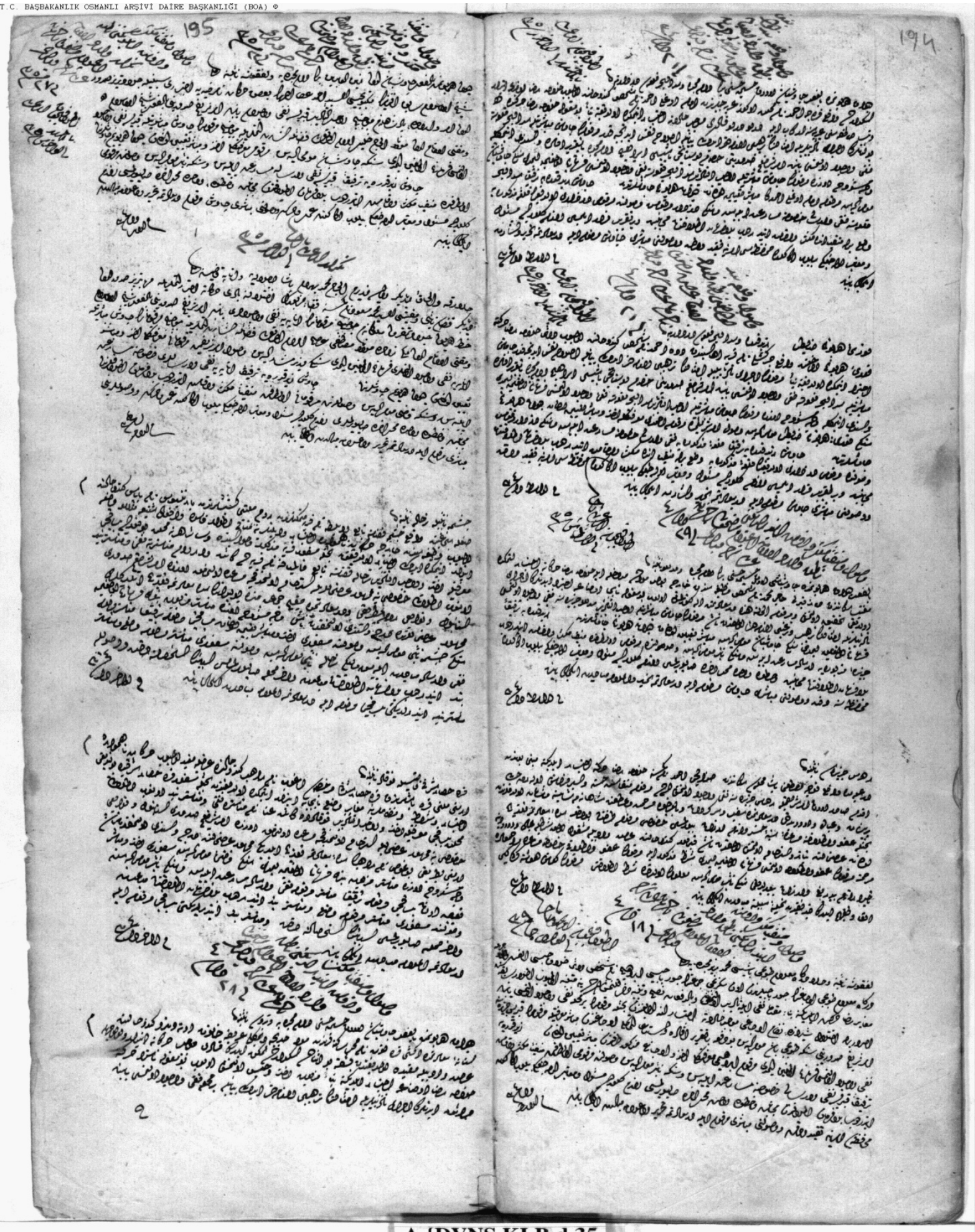

A.\{DVNS.KLB.d.35

Ermeni Milleti Karabaşlarından Karahisar-ı Şarkî Murahhasası Agob’unTokat Anna Manastırı'na Manastırbend Edilmesi Hakkındaki Belge,

BOA, A_DVNSKLB_d_00035_00100 (30 Zilkade 1234) 